\title{
Spatial Distribution and Source Identification of Heavy Metals in Surface Waters of Three Coastal Areas of Tunisia
}

\author{
Zaher Drira $^{1 *}$, Houda Sahnoun ${ }^{2}$, Habib Ayadi ${ }^{1}$ \\ ${ }^{1}$ Biodiversity and Aquatic Ecosystems UR/11ES72 Research Unit, Department of Life Sciences, \\ Sfax Faculty of Sciences, University of Sfax, Soukra Road Km 3.5. BP 1171 - PO Box 3000 Sfax, Tunisia \\ ${ }^{2}$ Coastal and Urban Environment Research Unit, IPEIS , P.C. 3000, Sfax, Tunisia
}

Received: 13 October 2016

Accepted: 4 December 2016

\begin{abstract}
The concentrations of selected dissolved trace elements (Ni 446-919 $\mu \mathrm{g} \mathrm{L} \mathrm{L}^{-1}$, Pb 383-1015, Fe 195739, Cu 217-318, Cr 156-336, Zn 9-236, Mn 0-187, Co 0-310, and Cd 26-77) were assessed in the surface water of 30 stations belonging to three coastal areas along the Gulf of Gabes, i.e., the southern (stations 1-10) and northern (stations 11-20) coastal areas of Sfax and the Ghannouch area (stations 2130) during October and November 2014. Results showed that dissolved metals in surface waters, which were analyzed by means of flame atomic absorption spectrophotometry, followed the concentration levels $(\mathrm{Pb}>\mathrm{Ni}>\mathrm{Fe}>\mathrm{Cu}>\mathrm{Cr}>\mathrm{Co}>\mathrm{Mn}>\mathrm{Cd}>\mathrm{Zn})$ on the southern and $(\mathrm{Ni}>\mathrm{Pb}>\mathrm{Fe}>\mathrm{Cu}>\mathrm{Cr}>\mathrm{Zn}>\mathrm{Mn}>\mathrm{Co}>\mathrm{Cd})$ on the northern coasts of $\mathrm{Sfax}$, and $(\mathrm{Ni}>\mathrm{Fe}>\mathrm{Pb}>\mathrm{Cu}>\mathrm{Cr}>\mathrm{Zn}>\mathrm{Co}>\mathrm{Cd}>\mathrm{Mn})$ in the Ghannouch area. In the southern and the northern coasts of Sfax, all analyzed metals were detected in $100 \%$ of sampled stations except Co, which was revealed in 90 and $80 \%$ of stations, respectively. However, in the Ghannouch area all analyzed metals were detected in $100 \%$ of sampled stations except Mn, which was revealed in $70 \%$ of stations. These trace elements, except for Fe and Mn, exceeded the safety limit of the USEPA water quality criteria for the protection of aquatic fauna and flora survival and their uses. The Sfax and Ghannouch coastal areas should be considered relatively polluted with metals $(\mathrm{Zn}, \mathrm{Ni}, \mathrm{Pb}, \mathrm{Co}, \mathrm{Cr}, \mathrm{Cd}$, and $\mathrm{Cu}$ ). The elevated metal contents were attributed to anthropogenic waste inputs around the study area. The main sources of $\mathrm{Ni}$ and Co loading in the seawater were the SIAPE phosphoric acid and fertilizer plant and a waste water treatment plant located close to station 1. Whereas the fishing harbor of Sfax, which is situated on the southern coast (station 9), is the second source of high amounts of $\mathrm{Cd}, \mathrm{Mn}, \mathrm{Cr}$, and $\mathrm{Pb}$. This situation has led to serious human health risks and chronic toxicity caused by their potential bioaccumulation in some aquatic fauna such as shrimp, fish, crab, shellfish, mollusk, and cephalopoda.
\end{abstract}

Keywords: trace element, anthropogenic impacts, safety limit, southern and northern coasts of Sfax, Ghannouch area

*e-mail: zaherdrira@yahoo.fr 


\section{Introduction}

Growing concern over the potential contamination of marine coastal ecosystems has gained momentum in recent years and become a priority issue [1-3]. Heavy metals in ecosystems have received extensive attention because they are toxic and non-biodegradable regarding their bioaccumulation in the environment, and easy to accumulate and magnify in organisms [4-10]. They are categorized as potentially toxic (e.g., $\mathrm{Cd}, \mathrm{Cr}, \mathrm{Co}, \mathrm{Pb}$, and $\mathrm{Ni}$ ) and essential (e.g., $\mathrm{Cu}, \mathrm{Zn}$, and $\mathrm{Fe}$ ) [11-14]. Among other contaminants, heavy metals in seawater have received particular attention as a way of assessing the impact of human activities on the marine environment $[3,11,15-16]$. Concentrations of heavy metals in aquatic ecosystems have increased considerably due to the inputs of industrial waste, sewage runoff, and agriculture discharge [17-18]. Anthropogenic activities and urban effluents are known to be significant sources of the metals, resulting in the deterioration of water quality with a longterm implication for human health and ecosystems [1920]. They are common pollutants that have severely deteriorated the aquatic ecosystems in different parts of the world [21-23]. Even at low concentrations, toxic metals can be very harmful to human health when ingested over a long period. Essential metals can also produce toxic effects with excessive intake [24-26]. In other words, heavy metal pollution may likely go hand in hand with rapid economic development $[5,27]$.

Over the last decades, several studies have been carried out both in the eastern [28-29] and western Mediterranean regions [30-31]. However, there is still a lack of information regarding the North African regions skirting the southern part of the Mediterranean. Tunisia, being one of these regions, could have sustained the simultaneous effect of transfrontier pollution and urban activities concentrated in its main coastal cities. In fact, Tunisia has a marine space spreading over than more 7 million hectares and including important characteristic ecosystems such as the Posidonia meadows and the coralligenous constructions. This area has been subjected to increasing pressure linked to the development of several activities on the coast and in the sea. The Gulf of Gabes (southwestern Mediterranean) is one of the most vulnerable aquatic ecosystems, contributing about $65 \%$ of national fish production in Tunisia [32-33], fauna biodiversity [34-38] and a wide distribution of Posidonia Oceanica, an endemic species representing a good nursery for fish eggs and larvae [39]. However, due to the increase of urbanization, industry, overfishing, tourism, and the discharge of huge amounts of phosphogypsum and other pollutants, the Gulf of Gabes has been reported to be densely polluted [40]. Sfax city (Tunisia), located on the southeastern Mediterranean Sea, is one of the main harbors of this gulf, and is an important industrial center whose pollution level is in contrast to nearby Kerkennah Island.

In 2009 the northern coast of Sfax was restored by cleaning a zone of 400 ha, removing 4.3 million $\mathrm{m}^{3}$ of polluted soil, including 1.7 million $\mathrm{m}^{3}$ of phosphogypsum, an industrial by-product of phosphoric acid produced from natural phosphate rock through the wet process [41]. This area was recently restored through the Taparura Project, which was aimed at remediating this part of Sfax city. The project included the rehabilitation of a former industrial site, cleaning-up beaches, and restoring the area [42]. Indeed, this zone was strongly polluted by the phosphogypsum wastes from the NPK phosphoric acid industry, situated near the commercial harbor. NPK was closed in 1992 and the Taparura Project allowed for the burial of the phosphogypsum wastes and the rehabilitation of the area between the commercial harbor and the zone of Sidi Mansour. On the northern coast, there are also the mouth of the rainwater draining channel ("PK4"), which crosses the city from southwest to northeast, and the outlet of the Wadi Ezzit, which receives untreated domestic and industrial effluents. However, the southern coast, which was not yet been restored, is under a great environmental pollution and harbors many anthropogenic and industrial activities. Although there have been a number of investigations on the impacts of pollutants such as hydrocarbons and nutrients (e.g., phosphate, nitrate, ammonium), total polyphenolic compounds and phosphogypsum wastes in the Sfax coast (e.g., [40, 43, 44]), the human and ecological risk from pollutants, namely heavy metals, have not yet been investigated in the gulf of Gabes. Indeed, the coastal zone of Sfax has been subjected to some investigations on trace metals in sediments [45] or in some seafood such as annular sea bream fish (Diplodus annularis), cow bream (Sarpa salpa), and cuttlefish (Sepia officinalis) [46], and in the marine bivalve Ruditapes decussatus [47-48], but data on the spatial distribution of dissolved trace metals in the surface seawater are scarce or absent.

To sum up, the purposes of this study are to:

1. Quantify and explain the spatial distribution and fractionations of nine metals $(\mathrm{Zn}, \mathrm{Ni}, \mathrm{Pb}, \mathrm{Co}, \mathrm{Fe}, \mathrm{Cr}$, $\mathrm{Cd}, \mathrm{Cu}$, and $\mathrm{Mn}$ ) in the surface water of 30 stations in the Sfax northern and southern coasts and Ghannouch area during October and November 2014 (Gulf of Gabes, Tunisia).

2. Explore the contamination degree and potential ecological risks.

3. Identify potential sources of contamination to these three marine coastal ecosystems by heavy metals.

This evaluation will help develop effective coastal management guidelines and strategies for better management of coastal activities.

\section{Material and Methods}

\section{Study Area}

The Gulf of Gabes (Eastern Mediterranean Sea, between $35^{\circ} \mathrm{N}$ and $33^{\circ} \mathrm{N}$, Tunisia) is endowed with rich aquatic resources contributing to about $65 \%$ of the national fish production in Tunisia [32]. Sampling was carried during October and November 2014 in three 
coastal areas: the Southern (hereafter called SC; stations 1-10) and northern (hereafter called NC; stations 11-20) coasts of Sfax and the Ghannouch area (hereafter called GA; stations 21-30) in the Gulf of Gabes. Ten sampling stations were chosen for each area, taking into account the pollution gradient (Fig. 1).

\section{Sampling}

Sampling was performed on board the vessel "Taparura" between 10:30 and 15:30 (18 and 23 October 2014), and 08:30 and 12:30 (13 November 2014) around high tide and under conditions of calm sea and sunny weather (18 and 23 October, 13 November 2014).

Seawater samples were collected at $\sim 0.1-\mathrm{m}$ depth using 4-1 Nalgene polycarbonate bottles. The bottles were opened below the water surface to avoid sampling of the surface microlayer. They were extensively washed with $1 \mathrm{M}$ hydrochloric acid $(\mathrm{HCl})$ and Milli-Q water before use to prevent the contamination of the bottles, rinsed three times with the respective sample before filling, and placed in cold and dark conditions after collection.

\section{Analysis}

Trace metals, i.e., cadmium (Cd), cobalt (Co), chrome $(\mathrm{Cr})$, copper $(\mathrm{Cu})$, iron $(\mathrm{Fe})$, nickel $(\mathrm{Ni})$, lead $(\mathrm{Pb})$, manganese $(\mathrm{Mn})$, and zinc $(\mathrm{Zn})$ were analyzed by means of flame atomic absorption spectrophotometry (AAS) (Perkin Elmer A-Analyst 200 instrument copyright @ 2007, version 6 model). Some characteristics of the metal trace analysis, e.g., absorption wavelength $\lambda(\mathrm{nm})$ were detected using UV radiation. Etalon concentration for each metal, detection limit ranges and certified standard are given in Table 1. Seawater samples were filtered under vacuum filtration with a $0.2 \mu \mathrm{m}$ porosity filter and underwent acid attack. The blank used to analyze the different heavy metals was composed of $100 \mathrm{ml}$ of water and 2 or 3 drops of $\mathrm{HCl}$.

\section{Data Processing and Statistical Analysis}

We applied geographic information systems (GIS) tools using ArcGIS 10.2 software to make contour plots. Kriging was the method used to build maps relative to spatial distribution for all dataset parameters.

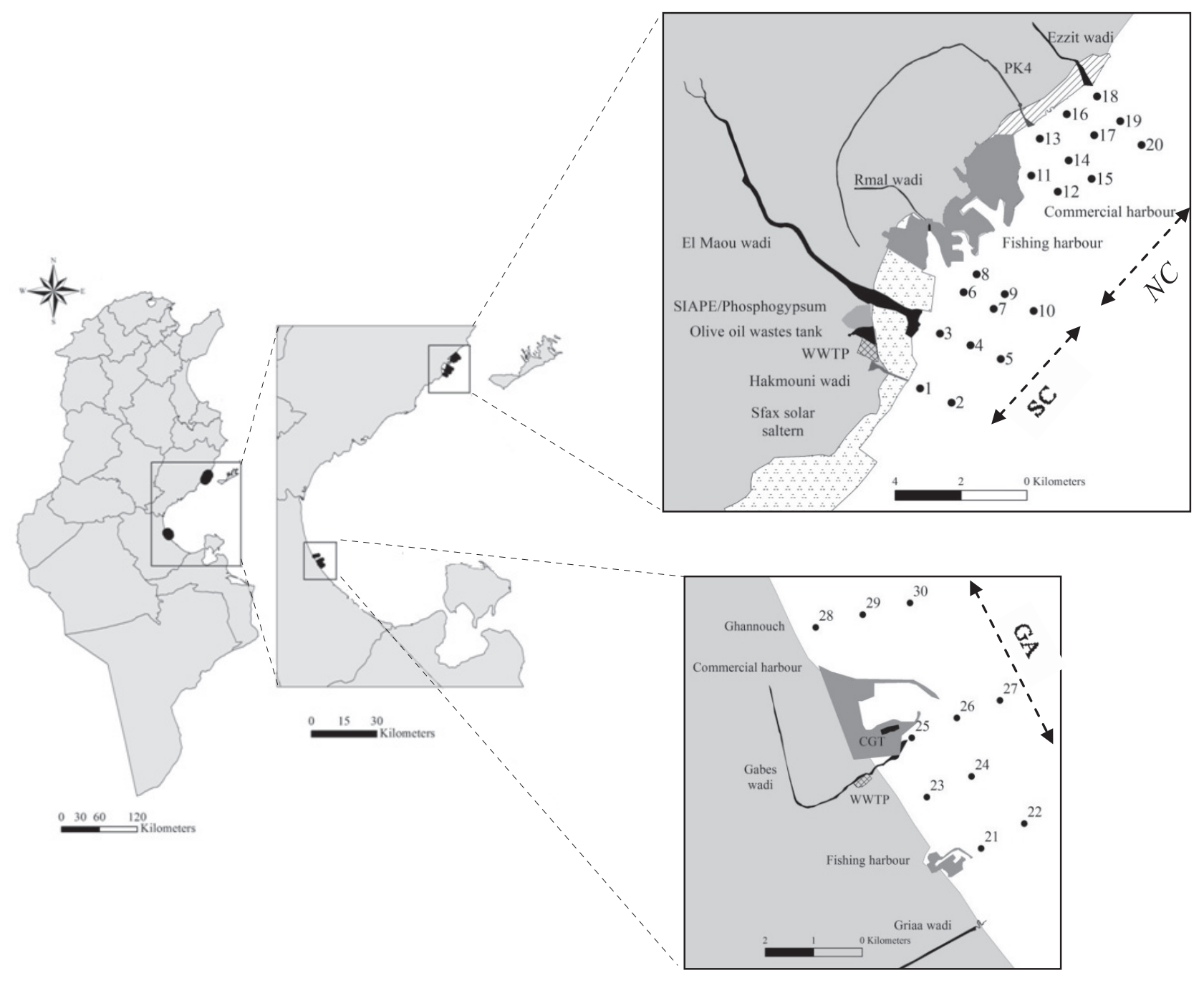

Fig. 1. Location of the studied stations in the southern (stations 1-10) and northern (stations 11-20) coastal areas of Sfax and the Ghannouch area (stations 21-30) sampled during autumn (October-November 2014). 
Table 1. Some characteristics of the metal trace analysis, such as UV wavelength absorption $\lambda(\mathrm{nm})$, etalon concentration, limit of detection, and standard certified for some trace metals (ND: Non Defined).

\begin{tabular}{|c|c|c|c|c|c|c|}
\hline $\begin{array}{l}\text { Trace metal } \\
\text { Levels }\end{array}$ & $\begin{array}{l}\text { Absorbance }: \lambda \\
(\mathrm{nm})\end{array}$ & Etalo & $\begin{array}{l}\text { onc } \\
\text { ng }\end{array}$ & ation & $\begin{array}{l}\text { Limit of detection } \\
\qquad\left(\mathrm{mg} \mathrm{l}^{-1}\right)\end{array}$ & Standard certified for some metal trace \\
\hline $\mathrm{Zn}$ & 213.86 & 1 & 3 & 5 & 0.012 & ND \\
\hline $\mathrm{Ni}$ & 232.00 & 1 & 5 & 10 & 0.07 & ND \\
\hline $\mathrm{Pb}$ & 283.31 & 1 & 3 & 5 & 0.085 & Lead AA standard $1,000 \pm 5 \mu \mathrm{g} \mathrm{ml}^{-1}$ in $2 \% \mathrm{HNO}_{3}$ \\
\hline Co & 240.73 & 1 & 3 & 5 & 0.075 & ND \\
\hline $\mathrm{Cu}$ & 324.75 & 1 & 5 & 10 & 0.035 & ND \\
\hline $\mathrm{Fe}$ & 248.33 & 1 & 5 & 10 & 0.08 & Iron AA standard $1,000 \pm 5 \mu \mathrm{g} \mathrm{ml}^{-1}$ in $2 \% \mathrm{Hcl}$ \\
\hline $\mathrm{Cr}$ & 357.81 & 0.5 & 1 & 1.5 & 0.05 & Chromium standard $1,000 \pm 5 \mathrm{\mu g} \mathrm{ml}^{-1}$ in $2 \% \mathrm{Hcl}$ \\
\hline $\mathrm{Cd}$ & 228.80 & 1 & 3 & 5 & 0.012 & ND \\
\hline
\end{tabular}

\section{Risk Assessment}

The Metal Pollution Index (MPI) represents the composite influence of all metals on water quality [49]. It represents the sum of the ratio between the concentration of analyzed metals and their corresponding maximum allowable concentrations (MAC) as used by [50] for $\mathrm{Zn}$, $\mathrm{Ni}, \mathrm{Pb}, \mathrm{Cr}, \mathrm{Cd}$, and $\mathrm{Cu}$, and by [51] for $\mathrm{Co}, \mathrm{Mn}$, and $\mathrm{Fe}$.

$$
M P I=\sum_{i=1}^{n} \frac{C i}{(M A C) i}
$$

...where the concentration of ' $\mathrm{i}^{\text {th' }}$ ' metal; MAC $=$ Maximum allowable concentrations. Water quality is categorized into six different classes depending on the degree of anthropogenic input of metals during various periods of sampling [52]. An MPI of $<0.3$ is very poor (Class I), 0.3-1.0 poor (Class II), 1.0-2.0 slightly affected (Class III), and 2.0-4.0 moderately affected (Class IV), 4.0-6.0 strongly affected (Class V), and an MPI $>6.0$ is seriously affected (Class VI) [11, 49].

\section{Results and Discussion}

Spatial Distribution of Dissolved Trace Metals in Surface Waters of Three Coastal Areas along the Gulf of Gabes

The spatial distribution of heavy metal concentrations in the sampled water is presented in Table 2 and Fig. 2. Trace metal concentrations in water samples was measured in the order $\mathrm{Ni}>\mathrm{Pb}>\mathrm{Fe}>\mathrm{Cu}>\mathrm{Cr}>\mathrm{Zn}>\mathrm{Mn}>\mathrm{Co}>\mathrm{Cd}$ (Table 2 and Fig. 2). All these estimated trace elements exceeded the permissible limit of the USEPA water quality criteria except Fe and $\mathrm{Mn}[50,51]$. Ni, Pb, and Fe contributed $68 \%$ of the total trace metals measured while the others did not exceed $32 \%$. Ni represented $26 \%$ and varied from 446 (station 5, SC) to $919 \mu \mathrm{g} . \mathrm{l}^{-1}$ (station $1, \mathrm{SC}$ ), with an average of $705 \pm 102 \mu \mathrm{g}^{-1}$ (Table 2 and
Fig. 2). $\mathrm{Pb}$ represented $23 \%$ and varied from 383 (station

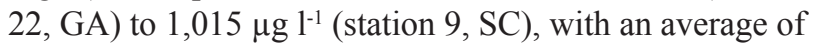
about $623 \pm 180 \mu \mathrm{g} \mathrm{l}^{-1}$ (Table 2 and Fig. 2). Fe averaged $505 \pm 135 \mu \mathrm{g} \mathrm{l}^{-1}$, varying from 195 (station 5, SC) to $739 \mu \mathrm{g} \mathrm{l}^{-1}$ (station 15, NC). Mn and Co were detected in $90 \%$ of samples, whereas $\mathrm{Ni}, \mathrm{Pb}, \mathrm{Fe}, \mathrm{Cu}, \mathrm{Cr}, \mathrm{Zn}$, and $\mathrm{Cd}$ were detected in $100 \%$ of the samples. $45 \%$ of the highest trace metal concentrations, i.e., $\mathrm{Pb}, \mathrm{Mn}, \mathrm{Cd}$, and $\mathrm{Cr}$ were measured at station 9 situated close to the fishing harbor in $\mathrm{SC}$ (Fig. 2). The most important concentrations of $\mathrm{Ni}$ and Co were observed in station 1 , situated close to the phosphoric acid and fertilizer plant, the WWTP, and Hakmouni wadi of SC. These sources are responsible for loading the seawater with chemically polluted wastes, notably $\mathrm{Ni}$ and Co (Fig. 2).

Most trace metals displayed significant differences between $\mathrm{NC}, \mathrm{SC}$, and $\mathrm{GA}$, i.e., $\mathrm{Pb}, \mathrm{Fe}, \mathrm{Cu}$, and $\mathrm{Zn}$ (ANOVA, $\mathrm{p}<0.0001$ ), Co and Mn (ANOVA, $<<0.001$ ), and $\mathrm{Ni}$ (ANOVA, $p<0.05)(p>0.01)$, except for $\mathrm{Cd}$ and $\mathrm{Cr}$ (ANO$\mathrm{VA}, \mathrm{p}<0.05)$. The near-shore coastal environments are the most marine ecosystems vulnerable to metal pollution due to intense activities of coastal inhabitants - most notably urbanization and industrialization [11]. The trace metals analyzed in surface water exhibited the following decreasing order: $(\mathrm{Pb}>\mathrm{Ni}>\mathrm{Fe}>\mathrm{Cu}>\mathrm{Cr}>\mathrm{Co}>\mathrm{Mn}>\mathrm{Cd}>\mathrm{Zn})$ on the $\mathrm{SC},(\mathrm{Ni}>\mathrm{Pb}>\mathrm{Fe}>\mathrm{Cu}>\mathrm{Cr}>\mathrm{Zn}>\mathrm{Mn}>\mathrm{Co}>\mathrm{Cd})$, on the $\mathrm{NC}$, and $(\mathrm{Ni}>\mathrm{Fe}>\mathrm{Pb}>\mathrm{Cu}>\mathrm{Cr}>\mathrm{Zn}>\mathrm{Co}>\mathrm{Cd}>\mathrm{Mn})$ in $\mathrm{GA}$.

A close look at the results showed mean concentrations of metals in surface water. In this study, metals such as Zn (9-236 $\left.\mu \mathrm{g} \mathrm{l}^{-1}\right)$, Ni (446-919 $\left.\mu \mathrm{g} \mathrm{l}^{-1}\right), \mathrm{Pb}$ (383-1015 $\left.\mu \mathrm{g} \mathrm{l}^{-1}\right)$, Co $\left(0-310 \mu \mathrm{g} \mathrm{l}^{-1}\right)$, Cr $\left(156-336 \mu \mathrm{g} \mathrm{l}^{-1}\right)$, $\mathrm{Cd}\left(26-77 \mu \mathrm{g} \mathrm{l}^{-1}\right)$, and $\mathrm{Cu}\left(217-318 \mu \mathrm{g} \mathrm{l}^{-1}\right)$ are among toxic chemicals that exceeded the safety limit of the USEPA water quality criteria. However, Fe (195-739 $\left.\mu \mathrm{g} \mathrm{l}^{-1}\right)$ and Mn $\left(0-187 \mu \mathrm{g} \mathrm{l}^{-1}\right)$ elements were within the allowed limits [50-51]. The same result was found in surface sediments from the Sfax-Kerkennah coastal zone (Tunisia) [53]. In fact, all analyzed metals (except for Fe and $\mathrm{Mn}$ ) can be considered as moderate to extreme pollutants, especially in Sfax Bay. Fe and Mn in the city of Sfax were derived from natural sources [53]. Industrial activity, shipyard 


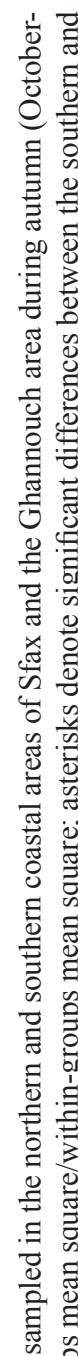

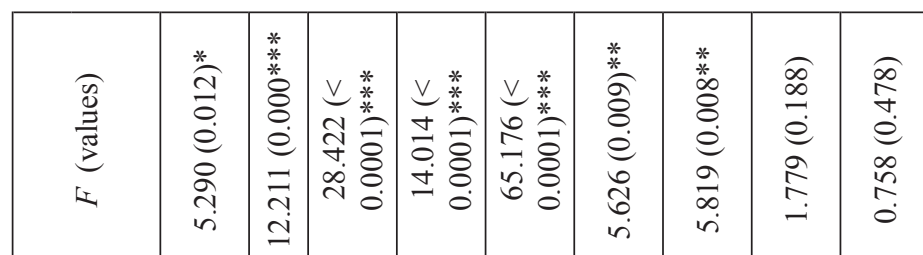

音

\begin{tabular}{|c|c|c|c|c|c|c|c|c|}
\hline 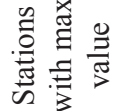 & - & $a$ & $n$ & ๑ & $\stackrel{\infty}{\sim}$ & - & $\circ$ & $a$ \\
\hline
\end{tabular}

\begin{tabular}{|c|c|c|c|c|c|c|c|c|}
\hline 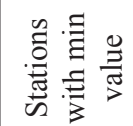 & in & त & in & in & in & $\begin{array}{l}\stackrel{\infty}{\square} \\
\stackrel{0}{+}\end{array}$ & $\begin{array}{l}\stackrel{+}{\Lambda} \\
\underset{\sim}{\sim}\end{array}$ & $\simeq$ \\
\hline
\end{tabular}

\begin{tabular}{|c|c|c|c|c|c|c|c|c|c|c|}
\hline 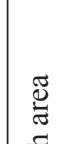 & $\begin{array}{l}\text { की } \\
\text { 1 } \\
\text { ह } \\
\sum_{0}^{0}\end{array}$ & $\begin{array}{l}n \\
i \\
+1 \\
2 \\
\hat{n}\end{array}$ & $\begin{array}{l}0 \\
0 \\
+1 \\
\hat{\sigma}\end{array}$ & $\begin{array}{l}\text { \& } \\
+ \\
\text { से }\end{array}$ & $\begin{array}{l}\text { ते } \\
+1 \\
\vec{\lambda}\end{array}$ & $\begin{array}{l}\text { ते } \\
+1 \\
\infty \\
\infty\end{array}$ & $\begin{array}{l}\stackrel{\oplus}{m} \\
+ \\
\vec{n}\end{array}$ & $\begin{array}{l}\stackrel{0}{ } \\
+ \\
\tilde{f}\end{array}$ & $\begin{array}{l}\stackrel{+}{H} \\
\forall\end{array}$ & $\begin{array}{l}\tilde{D} \\
H \\
n \\
\tilde{n}\end{array}$ \\
\hline
\end{tabular}

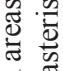

覀皆

동

焉

焉当

$\stackrel{0}{\Xi} \Xi$ 守*

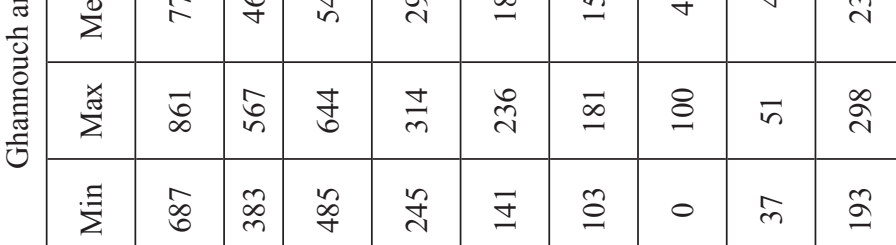

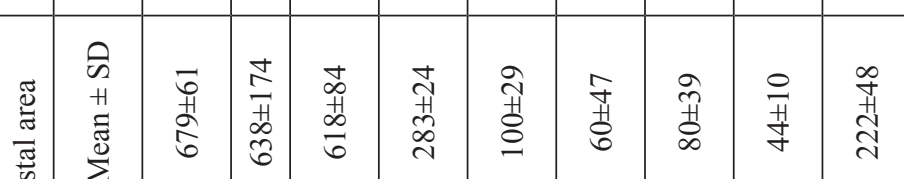

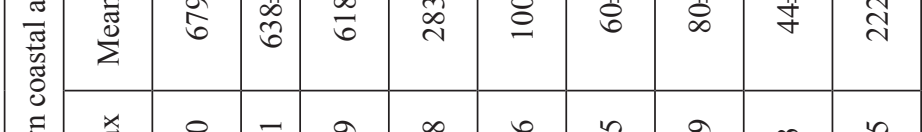

\begin{tabular}{|c|c|c|c|c|c|c|c|c|c|c|}
\hline$\underset{\mathbb{E}}{\mathbb{E}}$ & $\sum_{\Sigma}^{\varpi}$ & $\stackrel{\infty}{\curvearrowright}$ & $\bar{\Xi}$ & $\grave{\curvearrowright}$ & $\stackrel{\infty}{m}$ & $\stackrel{\imath}{n}$ & $\cong$ & ले & $\hat{n}$ & 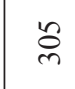 \\
\hline & $\stackrel{\Xi}{\Sigma}$ & î & $\underset{\sim}{\stackrel{一}{n}}$ & in & $\stackrel{\mathcal{I}}{\mathrm{J}}$ & in & 0 & $=$ & $\stackrel{\sim}{\sim}$ & \\
\hline
\end{tabular}

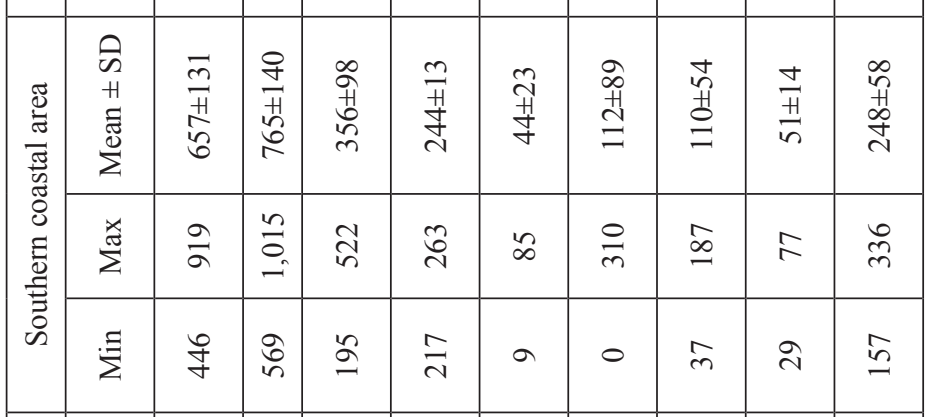

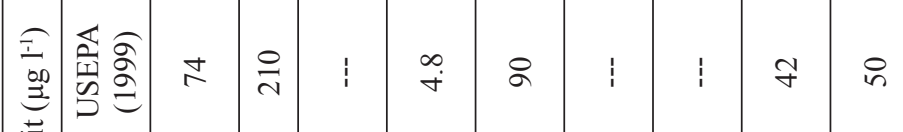

\begin{tabular}{|c|c|c|c|c|c|c|c|c|c|}
\hline & & & & & & & & & \\
\hline 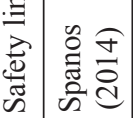 & $\begin{array}{l}n \\
\stackrel{n}{n} \\
\stackrel{n}{N}\end{array}$ & 志 & 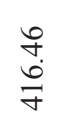 & 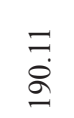 & $\begin{array}{l}\hat{\infty} \\
\text { : } \\
ٌ \vec{n}\end{array}$ & 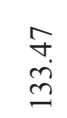 & $\frac{n}{2}$ & $\begin{array}{l}\vec{N} \\
\stackrel{\infty}{\infty}\end{array}$ & $\frac{0}{5}$ \\
\hline
\end{tabular}

\begin{tabular}{|c|c|c|c|c|c|c|c|c|c|}
\hline 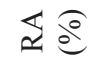 & ర్ర & $\tilde{\lambda}$ & 2 & 은 & $\nabla$ & $\checkmark$ & $m$ & $\sim$ & $a$ \\
\hline to & 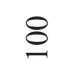 & ¿ & @ & $\nsubseteq$ & $\nsubseteq$ & 8 & \& & 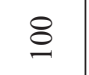 & @ \\
\hline 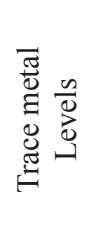 & 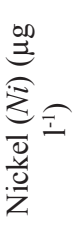 & 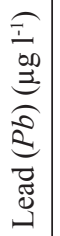 & 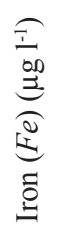 & 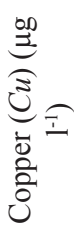 & 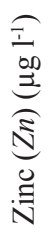 & 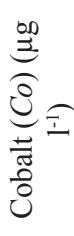 & 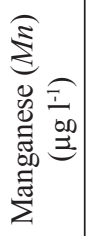 & 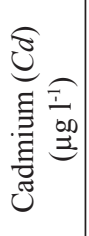 & 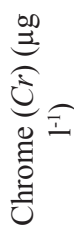 \\
\hline
\end{tabular}



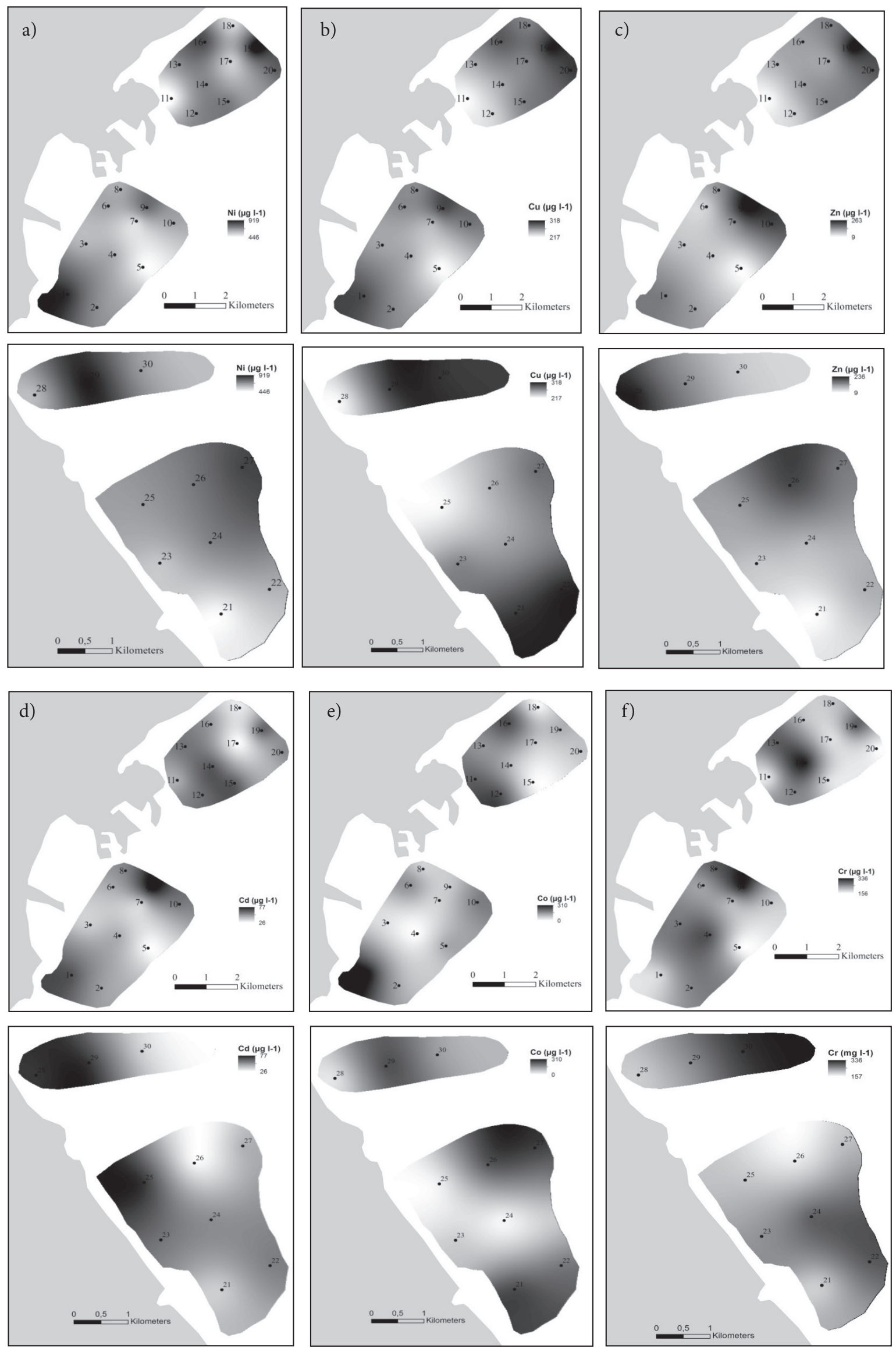

Fig. 2. Spatial variation Iron of trace metals, i.e., nickel (Ni) a), copper $(\mathrm{Cu})$ b), zinc $(\mathrm{Zn}) \mathrm{c})$, cadmium $(\mathrm{Cd}) \mathrm{d})$, cobalt $(\mathrm{Co})$ e), chrome $(\mathrm{Cr}) \mathrm{f})$, lead $(\mathrm{Pb}) \mathrm{g}$ ), manganese $(\mathrm{Mn}) \mathrm{h}$ ), and iron (Fe) i) at stations sampled in the northern and southern coastal areas of Sfax and the Ghannouch area during autumn (October-November 2014). 

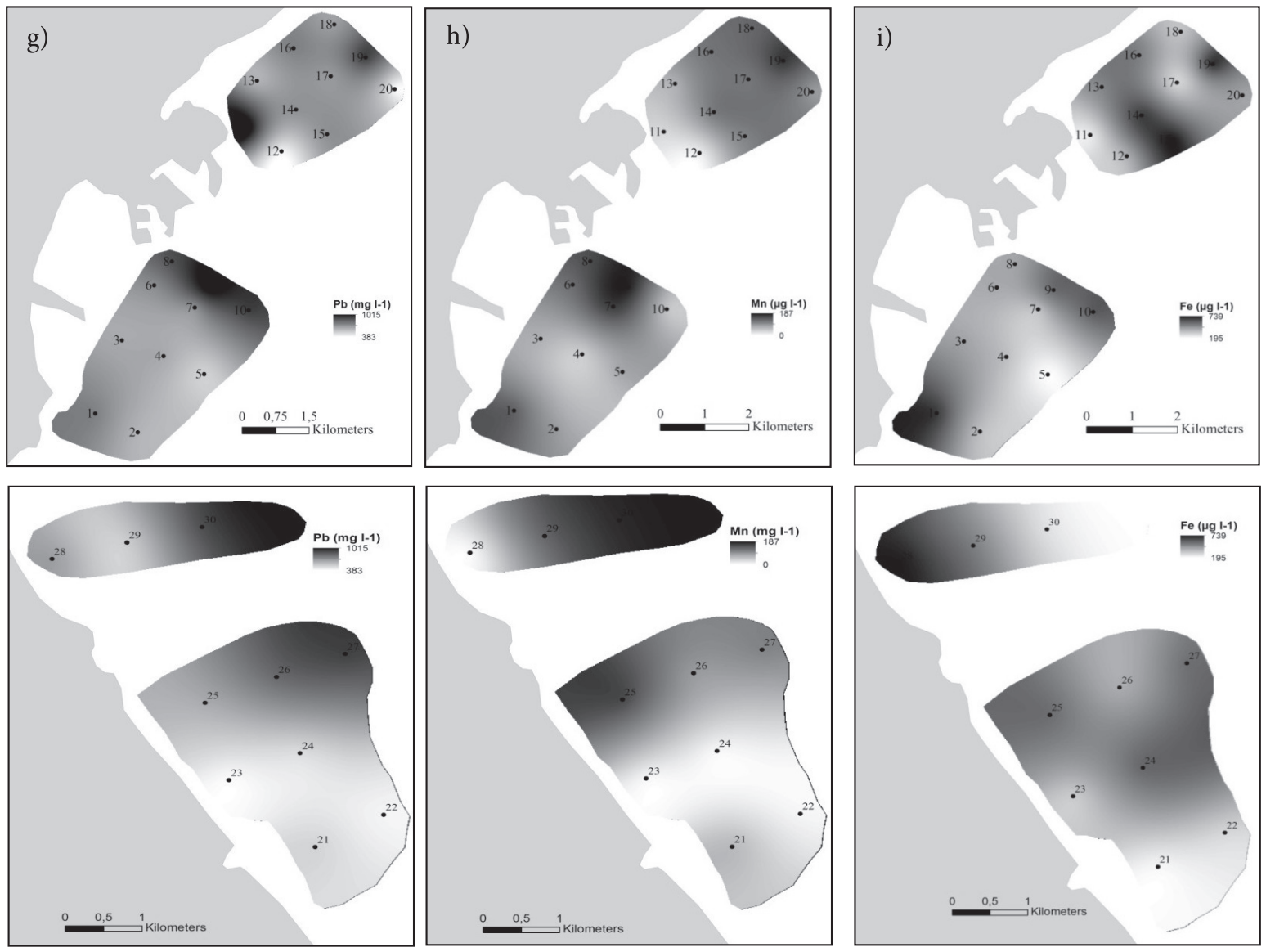

Fig. 2. Continued.

and shipping activity in coastal marine ecosystems have a negative impact on water quality, because heavy metals from water can be poisonous to organisms and can lead to a decrease in the productivity in marine fisheries, marine culture, and biodiversity [54]. This was the case of SC, in which the high rate of dissolved heavy metals in water could also accumulate in sediments and fish [55].

The only study concerning the heavy metal levels in Gulf of Gabes seawater was conducted in SC [56]. They showed that heavy metal concentrations decreased in the order $\mathrm{Fe}>\mathrm{Ni}>\mathrm{Zn}>\mathrm{Cu}>\mathrm{Pb}>\mathrm{Cd}$. Compared to our results, the highest contents of the different metals analyzed in this study were relatively lower $\mathrm{Cd}\left(0.21 \mu \mathrm{g} \mathrm{l}^{-1}\right), \mathrm{Cu}\left(4.34 \mu \mathrm{g} \mathrm{l}^{-1}\right)$, Fe $\left(30.74 \mu \mathrm{g} \mathrm{l}^{-1}\right)$, $\mathrm{Ni}\left(10.21 \mu \mathrm{g} \mathrm{l}^{-1}\right), \mathrm{Pb}\left(3.43 \mu \mathrm{g} \mathrm{l}^{-1}\right)$, and $\mathrm{Zn}\left(5.78 \mu \mathrm{g} \mathrm{l}^{-1}\right)$ [56]. These differences of concentrations were due to the fact that seawater samples were collected in front of the different sources of pollution. The mean concentrations of metals in surface waters in this study were lower than for other Mediterranean polluted areas as reported by Abdallah (2008) [57] from El-Mex Bay along the Alexandria coast (Egypt, Mediterranean Sea). The dissolved trace metals analyzed followed the order $\mathrm{Zn}>\mathrm{Pb}>\mathrm{Co}>\mathrm{Cu}>\mathrm{Cr}>\mathrm{Cd}$. They reached $33.6 \pm 12.7 \mathrm{mg}$ $\mathrm{l}^{-1}$ for $\mathrm{Zn}, 14.19 \pm 7.5 \mathrm{mg} \mathrm{l}^{-1}$ for $\mathrm{Pb}, 14.15 \pm 5.5$ for Co mg $\mathrm{l}^{-1}, 4.29 \pm 0.46$ for $\mathrm{Cu} \mathrm{mg} \mathrm{l^{-1 }}, 47.58 \pm 14.3 \mathrm{mg} \mathrm{l}^{-1}$ for $\mathrm{Fe}$, $3.68 \pm 1.7 \mathrm{mg} \mathrm{l}^{-1}$ for $\mathrm{Cr}$, and $3.1 \pm 2.1$ for $\mathrm{Cd} \mathrm{mg} \mathrm{l}^{-1}$.
In other Mediterranean regions such as Lake Manzala, Egypt, the mean concentration of the measured metals in water was found to be in the order: $\mathrm{Zn}\left(0.311 \mathrm{mg} \mathrm{l}^{-1}\right)>\mathrm{Cu}\left(0.055 \mathrm{mg} \mathrm{l}^{-1}\right)>\mathrm{Pb}\left(0.022 \mathrm{mg} \mathrm{l}^{-1}\right)>$ $\mathrm{Cd}\left(0.020 \mathrm{mg} \mathrm{l}^{-1}\right)$ [14], which are lower than the concentrations in the present study. In other Tunisian regions such as the lagoon of Boughrara, heavy metals were measured in the following order: $\mathrm{Cu}>\mathrm{Al}>\mathrm{Pb}>\mathrm{Cd}>\mathrm{Cr}>\mathrm{Hg}$, with concentrations of $7,080 \pm 400,368 \pm 690,173 \pm 230,260 \pm 230$, $180 \pm 20$, and $110 \pm 650 \mu \mathrm{g} \mathrm{l}^{-1}$ as measured in 2008 [58]. These results obtained from Boughrara Lagoon showed that some trace elements (i.e., $\mathrm{Cu}$ and $\mathrm{Cd}$ ) were relatively higher than in the SC, which represented $273 \pm 28$ and $46 \pm 10 \mu \mathrm{g} \mathrm{l}^{-1}$, respectively. However, $\mathrm{Cr}\left(234 \pm 46 \mu \mathrm{g} \mathrm{l}^{-1}\right)$ and $\mathrm{Pb}\left(623 \pm 179 \mu \mathrm{g} \mathrm{l}^{-1}\right)$ were most important in our study than in Boughrara Lagoon. The elevated concentration of trace metals such as $\mathrm{Cr}$ and $\mathrm{Pb}$ is explained by industrial waste, sewage, and mainly harbor pollution [58]. The various heavy metals in seawater are sited in other marine regions, which become toxic if present in excessive quantities and pose a potential threat to the ecosystem [58].

The level of metal pollution in water samples was assessed through the metal pollution index. The estimated pollution evaluation indices for the assessed metals exhibited a variation among the three studied Gulf of Gabes areas as per the dissolved metal load in the marine water. GA (9.31) showed higher MPI values than NC (8.89) and SC (8.05), implying relatively high 


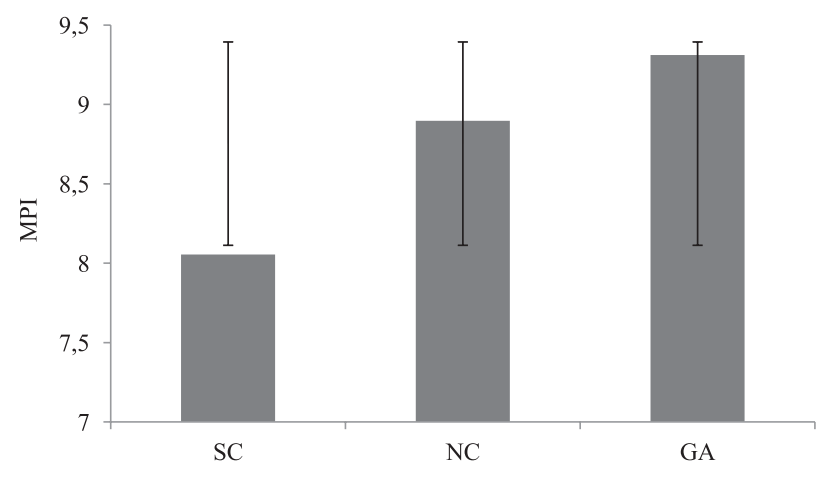

Fig. 3. Bar chart showing Metal Pollution Index (MPI) values in the three studied areas at stations sampled in the northern and southern coastal areas of Sfax and the Ghannouch area during autumn (October-November 2014).

concentrations of metals during this period. It is inferred from the indices calculated for the entire study period that MPI $>6.0$ represents seriously affected stations (Class VI) (Fig. 3). The MPI showed that Sfax and Ghannouch coastal areas were seriously affected (MPI of $>6.0$, Class VI) by the trace metal pollutants [11, 49].

\section{Origin of Trace Element Loading in Surface Waters in Three Gulf of Gabes Coastal Areas}

During the last decade, the coastal environment of the Gulf of Gabes experienced intense development in industry, urbanization, and aquaculture. Several metals are known to be discharged frequently through industrial and domestic effluents along the coast. The present study was carried out to determine heavy metal distribution in coastal waters. The sampling of coastal water was carried out during October and November 2014. The enrichment in the concentration of heavy metals in the samples taken close to the coastal areas, indicating that higher concentra-

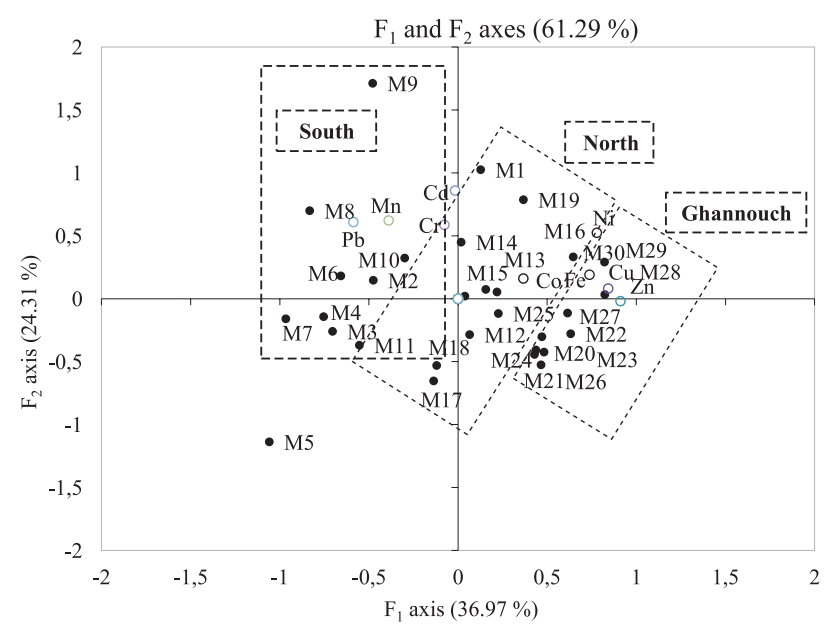

Fig. 4. Canonical correspondence analysis (CCA) (Axis I and II) on mean values of several trace metals in stations sampled in the northern and southern coastal areas of Sfax and the Ghannouch area sampled during autumn (October-November 2014). tions were due to the anthropogenic activities in the coastal area. The canonical correspondence analysis (CCA) on the studied trace metals explained $61.29 \%$ for the $\mathrm{F}_{1}$ and $\mathrm{F}_{2}$ axes (Fig. 4). The $\mathrm{F}_{1}$ axis (36.97\%) selected negatively SC stations (2-10) with $\mathrm{Pb}, \mathrm{Mn}, \mathrm{Cd}$, and $\mathrm{Cr}$, which were high in station 9 situated close to the fishing harbor of SC. The $F_{1}$ axis selected positively GA stations (21-30) with $\mathrm{Zn}$. The high concentration was recorded in station 28 , which was near the commercial harbor. NC stations (1120) with station 1 belonging to SC did not show a regular pattern. Some stations were selected positively and others negatively with a high concentration of $\mathrm{Ni}, \mathrm{Co}$, and $\mathrm{Fe}$ (Fig. 4). The CCA analysis confirms our results that the phosphoric acid and fertilizer plant, the WWTP, and the Hakmouni wadi (located in front of station 1) are responsible for loading the seawater with chemically polluted compounds - notably $\mathrm{Ni}$ and Co. Meanwhile, the fishing harbor of Sfax is the second source of trace metal pollution in $\mathrm{SC}$ (primarily $\mathrm{Cd}, \mathrm{Mn}, \mathrm{Cr}$, and $\mathrm{Pb}$ ) (located in front of station 9). Station 28 was near the commercial harbor and belonged to GA with a high concentration of $\mathrm{Zn}$. The Gabes region in southeastern Tunisia, is a polluted area where such a situation is expected to contribute to the transfer of heavy metals from the marine to the bordering terrestrial ecosystems [59]. This area is nowadays considered as a pollution hotspot mainly due to the operation of the Gabes-Ghannouch factory complex of phosphate treatment for acid and fertilizer production since the early 1970s [60]. With the absence of scavenging processes and treatment plants for industrial wastes, persistent toxic elements and heavy metals find their way into the sea. Alarmingly, 10,000 to 12,000 tons of phosphogypsum, containing heavy metals (mainly $\mathrm{Cd}$, $\mathrm{Pb}, \mathrm{Zn}, \mathrm{Cu}$, and $\mathrm{Cr}$ ), are released in the sea of GA per day [59-61]. Previous studies have shown high levels of heavy metals in the coastal sediments close to the industrial complexes [61-62]. Particularly high concentrations were recorded in the site where the effluents are released: $\mathrm{Cd}>100 \mu \mathrm{g} \mathrm{l}^{-1}, \mathrm{~Pb} 10-12 \mu \mathrm{g} \mathrm{l}^{-1}, \mathrm{Zn}>1,000 \mu \mathrm{g} \mathrm{l}^{-1}$, $\mathrm{Cu} 50-60 \mu \mathrm{g} \mathrm{l}^{-1}$, and $\mathrm{Cr} 100-120 \mu \mathrm{g} \mathrm{l}^{-1}[59,61]$.

The most important $\mathrm{Ni}$ and Co concentrations were observed in station 1, situated close to the phosphoric acid and fertilizer plant. Indeed, the phosphogypsum stock enriches the seawater with dehydrated calcium sulfate and heavy metals like cadmium, zinc, chromium, copper, cobalt, nickel, and lead $[41,55]$. Phosphate industry in the city of Sfax (production of crude phosphate, phosphoric acid, and fertilizer), urban agglomerations, and industrial zone [63] can release high amounts of heavy elements such as $\mathrm{Ni}$ and Co.

The second source of trace metal pollution is the fishing harbor in the $\mathrm{SC}$ (primarily $\mathrm{Cd}, \mathrm{Mn}, \mathrm{Cr}$, and $\mathrm{Pb}$ ). The spatial distribution of $\mathrm{Cr}, \mathrm{Cd}, \mathrm{Ni}, \mathrm{Zn}, \mathrm{Cu}$, and $\mathrm{Pb}$ concentrations in surface sediments from the coastal zone permit the identification of a highly contaminated zone in the vicinity of Sfax harbor [53]. These factors, combined with very shallow water, do not allow sufficient mixing with "clean" sediment to dilute terrigenous polluted loads. All analyzed metals (except for Fe and Mn) can be 
considered as moderate to extreme pollutants, especially along the Sfax coast [53]. In general, the present study showed that metal pollution has decreased in most of the studied sites along the Tunisian coast, although in Bizerta Channel, the fishing harbor of Gabes, and at Menzel Jemil, some contamination was still evident in 2011 [63]. In the southern region of the Gulf of Gabes, $\mathrm{Cd}$ concentrations were highest among the studied sites. In this area, the major factor behind this metallic pollution by heavy metals is phosphogypsum wastes, as shown in several previous works [61, 64-67]. Indeed, high amounts of phosphogypsum are discharged by the phosphate industry in the Gulf of Gabes, quantified at 11,250 tons per day and stretching along large surfaces in the open sea with deleterious effects on biota $[60,64-65,68]$. These discharges contain various metals, including $\mathrm{Cd}$ (39.8 $\left.\mathrm{mg} \mathrm{kg}^{-1}\right), \mathrm{Zn}\left(315 \mathrm{mg} \mathrm{kg}^{-1}\right), \mathrm{Cu}\left(5.9 \mathrm{mg} \mathrm{kg}{ }^{-1}\right), \mathrm{Ni}$ (15.4 $\left.\mathrm{mg} \mathrm{kg}^{-1}\right), \mathrm{Fe}\left(58.4 \mathrm{mg} \mathrm{kg}^{-1}\right)$, and others like $\mathrm{Hg}$, Mo, Co, and F [69]. According to Kharroubi et al. (2012) [66], the amounts of metals found in the flux of the principal effluents from the industrial pole of Gabes are estimated at $300 \mathrm{~kg}$ day ${ }^{1}$ for $\mathrm{Cd}, 200$ for $\mathrm{Cu}, 3,500$ for $\mathrm{Zn}, 50$ for $\mathrm{Pb}$, 250 for Mn, and 9,330 for Fe.

Industrial pollution in Tunisian waters is partly caused by the major industries and first of all by the natural phosphates processing industry. The chemical complex of Sfax and Gabes is thus responsible for pollution with massive ocean dumping of millions of tons of highly acidic phosphogypsum waste water, and heavy metals (e.g., cadmium). However, highly polluting tanneries located near the coast are responsible for organic matter, sulphides, and $\mathrm{Cr}$ as the main trace element load and paper industry (mercury) [70]. In comparison, the concentration of Fe $\left(22,000 \mu \mathrm{g} \mathrm{l}^{-1}\right), \mathrm{Zn}\left(21,100 \mu \mathrm{g} \mathrm{l}^{-1}\right), \mathrm{Cd}\left(370 \mu \mathrm{g} \mathrm{l}^{-1}\right)$, and $\mathrm{Pb}\left(210 \mu \mathrm{g} \mathrm{l}^{-1}\right)$ in the waste water from SIAPE [70] were lower than those detected in our sampling area, except for $\mathrm{Pb}$ (383-1,015 $\left.\mu \mathrm{g} \mathrm{l}^{-1}\right)$. This showed that $\mathrm{Pb}$ did not only emanate from the SIAPE facility but also from other sources of pollution.

Based on this research, land-based activities, sewage disposal from vessels, and residential areas close to harbors are the main sources of metal pollution in the Gulf of Gabes. The high level of $\mathrm{Pb}$ in the fishing harbor of the SC could be attributed to the spill of leaded petrol from fishing boats and dust, which holds a huge amount of lead from the combustion of petrol [71-72]. The same source of metal pollution was found in the fishing harbor of the Gulf of Chabahar [72] and along the Jeddah Red Sea Coast [71]. Indeed, $\mathrm{Pb}$ is used in a number of industrial applications and has been used as an anti-knocking additive in gasoline and is deposited following combustion [73]. In terms of anthropogenic activities, SC harbors 600 fishing boats (i.e., trawlers, sardine boats, tuna boats, and small artisanal boats) [63]. Furthermore, our results showed that the high concentration in $\mathrm{Zn}$ was revealed in GA in station 28 close to commercial harbor. $\mathrm{Zn}$ contamination could be related to phosphogypsum residues generated by the phosphate industry. Indeed, high $\mathrm{Zn}$ concentrations in sediments were reported in the outer fishing harbor of
Gabes, with values reaching $1,200 \mu \mathrm{g} \mathrm{g}^{-1} \mathrm{dw}$ in July 2010 $[61,63]$ and $7,165 \mu \mathrm{g} \mathrm{g}^{-1} \mathrm{dw}$ during September 2013 in Chatt Essalem, close to the fishing harbor $[63,67]$. The major sources of $\mathrm{Zn}$ are domestic and municipal wastes, followed by dumping and atmospheric deposition [7476]. These trace elements were measured in the lixiviate water near the phosphogypsum dump site by Zairi and Rouis (1999) [77], and revealed the following important concentrations, i.e., $35.6 \mathrm{mg} \mathrm{l}^{-1}$ for $\mathrm{Zn}, 0.53 \mathrm{mg} \mathrm{l}^{-1}$ for $\mathrm{Hg}$, and $2.03 \mathrm{mg} \mathrm{l}^{-1}$ for $\mathrm{Ni}$.

The primary anthropogenic sources of zinc in the environment (air, water, soil) are related to mining and metallurgical operations involving zinc and the use of commercial products containing zinc [78]. Domestic waste, shipyard, automotive, and industrial effluent are the sources of $\mathrm{Zn}$ to the aquatic environment. Besides, household wastes, including powder and liquid laundry detergents, shampoos, toilet tissue and other cleaning products, may also contribute to the zinc load in the aquatic environment [79]. Nickel is a naturally occurring element widely used in many industrial applications for the shipbuilding, automobile, electrical, oil, food, and chemical industries [80]. The major sources of $\mathrm{Ni}$ in the ocean are domestic wastewater effluents (boating activities) and metal smelters, which later accumulate in the biota - particularly in the phytoplankton or other aquatic plants [81]. Pb can be introduced into the aquatic environment through soil erosion, as atmospheric dust, by oil combustion, domestic and industrial landfills, and precipitation [82]. Lead is ubiquitous in the aquatic ecosystem and it is bioaccumulative. It is present as an inorganic or organic element [83]. The toxicity of lead depends on fish age, $\mathrm{pH}$, and water hardness [84]. Many toxic heavy metals such as $\mathrm{Hg}, \mathrm{Ni}$, and $\mathrm{Pb}$ influence water quality due to their chromic toxicity and persistence, and the potential to be bioaccumulated in many aquatic organisms such as shrimp, fish, crab, shellfish, mollusks, and cephalopoda [58, 85-90]. This result confirms our findings that the most important concentration of heavy metals was recorded in stations 1 and 2, which were situated in front of the fishing harbor (transect 1). The occurrence frequency of these two stations is characterized by maximum values of the different analyzed heavy metals (about $80 \%$ ). These stations were also sampled in 2011, showing that $\mathrm{Zn}, \mathrm{Pb}$, and $\mathrm{Ni}$ were the most common metals, representing 21.79 \pm 2.96 , $2.39 \pm 0.92$, and $2.25 \pm 0.82 \mathrm{mg} \mathrm{l}^{-1}$, respectively [91]. It seemed that the pollution level in SC has risen between 2011 and 2013 by the increasing heavy metals pollution discharge into seawater. During the present study, the measurement of these metals in stations 1 and 2 revealed 137.68-98.04 $\mathrm{mg} \mathrm{l}^{-1}$ for $\mathrm{Zn}, 3.774-0.951 \mathrm{mg} \mathrm{l}^{-1}$ for $\mathrm{Pb}$, and $18.549-1.739 \mathrm{mg} \mathrm{l}^{-1}$ for $\mathrm{Ni}$. We infer that the fishing activities in the SC seawater contributed to high organic loads of pollution characterized by important heavy metal contents exceeding the permissible limit [50-51]. The increase of the heavy metal contents also involves $\mathrm{Cd}$, which showed in this study the lowest mean value concentration $\left(5.1 \pm 5.5 \mu \mathrm{g} \mathrm{l}^{-1}\right)$ compared to previous 
works carried out in $2005\left(0.61 \pm 0.02 \mu \mathrm{g} \mathrm{l}^{-1}\right)$ [92]. These waste waters are discharged into the sea and the pollution greatly affects the ecological balance of this zone, plus the yields of fish and seafood toward biological accumulation [93]. Moreover, Fe is usually present in extremely low concentrations in oceanic surface waters and is one of the elements that limit phytoplankton growth [94].

\section{Conclusions}

The study of heavy metal distribution in coastal waters is an important component in understanding the distribution levels as well as assessing the cause of anthropogenic influences on the marine ecosystem. Results show that the commercial harbor of GA, the SIAPE manufactory in Sfax (production of phosphate, phosphoric acid, and fertilizer), and the fishing harbor of the SC were contaminated, respectively, by high amounts of $\mathrm{Zn}$, Ni$\mathrm{Co}$, and $\mathrm{Cd}$, and $\mathrm{Mn}, \mathrm{Cr}$, and $\mathrm{Pb}$ were the main sources of heavy metals pollution in the Gulf of Gabes. The results revealed that the fishing port is subject to allochthonous pollution input, which exerts a strong influence on the concentration of heavy metals in the seawater of the SC. The heavy metal levels recorded in this study, which exceeded the permissible limits $(\mathrm{Zn}, \mathrm{Ni}, \mathrm{Pb}, \mathrm{Co}, \mathrm{Cr}, \mathrm{Cd}$, and $\mathrm{Cu}$; except the $\mathrm{Fe}$ and $\mathrm{Mn}$ elements), altered the marine structure and functioning of this polluted ecosystem. This situation leads to serious human health risks caused by their potential bioaccumulation in some seafood in the SC. For this reason, this study proves the need for effective treatment and management measures for industrial effluents and other anthropogenic discharges into the SC waters so as to reduce the impact of heavy metal pollution.

Some heavy metals such as $\mathrm{Zn}, \mathrm{Ni}, \mathrm{Pb}, \mathrm{Co}, \mathrm{Cr}, \mathrm{Cd}$, and $\mathrm{Cu}$ analyzed in the present study are required as a chemical marker under a future project of monitoring programs, management, and restoration in SC for reliable estimates of water quality. The use of these biomarkers is recognized as an important approach for the assessment of pollution, as chemical analysis of environmental samples alone provide evidence of impacts of contaminants in the studied biota. Moreover, additional anthropogenic inputs of heavy metals in the Gulf of Gabes might be critical not only to vulnerable and fragile ecosystems, but also to human health.

\section{Acknowledgements}

This work was conducted in the Biodiversity and Aquatic Ecosystems UR/11ES72 Research Unit at the University of Sfax. This study was carried out within the framework of the postdoctoral fellowship of Zaher DRIRA (University of Sfax, Tunisia). The authors acknowledge Mr. Tarek Omar and Mr. Hammouda Sahnoun for their technical help during the cruise. We gratefully acknowledge extensive education to the common services to the Macromolecular Biochemistry and Genetics (BMG)
Research Unit of Gafsa Faculty of Sciences, Tunisia for metal concentrations analysis by atomic absorption spectrophotometetry (AAS). The authors are equally grateful to Kamel MAALOUL, translator and English professor, for having proofread the manuscript.

\section{References}

1. CARDOSO A.G.A., BOAVENTURA G.R., FILHO E.V.S., BROD J.A. Metal distribution in sediments from the Ribeira Bay, Rio de Janeiro, Brazil. J. Braz. Chem. Soc. 12, 767, 2001.

2. EL-SEREHY H.A., ABOULELA H., AL-MISNED F., KAISER M., AL-RASHEID K., EZZ EL-DIN H. Heavy metals contamination of a Mediterranean Coastal Ecosystem, Eastern Nile Delta, Egypt. Turkish J. Fish. Aquat. Sci. 12, 751, 2012.

3. AL-TAANI A.A., BATAYNEH A., NAZZAL Y., GHREFAT H., ELAWADI E., ZAMAN H. Status of trace metals in surface seawater of the Gulf of Aqaba, Saudi Arabia. Mar. Pollut. Bull. 86, 582, 2014.

4. ZHOU F., GUO H., HAO Z. Spatial distribution of heavy metals in Hong Kong's marine sediments and their human impacts: A GIS based chemometric approach. Mar. Pollut. Bull. 54, 1372, 2007.

5. GAO X.L., CHEN C.T.A. Heavy metal pollution status in surface sediments of the coastal Bohai Bay. Water Res. 46, 1901, 2012.

6. GU Y., YANG Y., LIN Q., LI Q., WANG Z., WANG X. Spatial, temporal, and speciation variations of heavy metals in sediments of Nanao Island, a representative mariculture base in Guangdong coast, China. J. Environ. Monit. 14, 1943, 2012.

7. HU B., LI J., ZHAO J., YANG J., BAI F., DOU Y. Heavy metal in surface sediments of the Liaodong Bay, Bohai Sea: distribution, contamination, and sources. Environ. Monit. Assess. 185, 5071, 2013.

8. BHATTACHARYA B.D., HWANG J.S., TSENG L., SARKAR S.K., RAKSHIT D., MITRA S. Bioaccumulation of trace elements in dominant mesozooplankton group inhabiting the coastal regions of Indian Sundarban mangrove wetland. Mar. Pollut. Bull. 87, 345, 2014.

9. JIANG X., TENG A., XU W. AND LIU X. Distribution and pollution assessment of heavy metals in surface sediments in the Yellow Sea. Mar. Pollut. Bull. 83, 366, 2014.

10. ZHUANG W., GAO X. Integrated Assessment of Heavy Metal Pollution in the Surface Sediments of the Laizhou Bay and the Coastal Waters of the Zhangzi Island, China: Comparison among Typical Marine Sediment Quality Indices. PLoS. ONE 9:94145, 2016.

11. ACHARY M.S., PANIGRAHI S.N., SATPATHY K.K., PRABHU R.K., PANIGRAHY R.C. Health risk assessment and seasonal distribution of dissolved trace metals in surface waters of Kalpakkam, southwest coast of Bay of Bengal. Reg. Stud. Mar. Sci. 6, 96, 2016.

12. BRUINS M.R., KAPIL S., OEHME F.W. Microbial resistance to metals in the environment. Ecotox. Environ. Safe. 45, 198, 2000.

13. NICOLAU R., GALERA-CUNHA A., LUCAS Y. Transfer of nutrients and labile metals from the continent to the sea by a small Mediterranean river. Chemosphere. 63, 469, 2006.

14. BAHNASAWY M., KHIDR A.A., DHEINA N. Assessment of heavy metal concentrations in water, plankton, and fish of Lake Manzala, Egypt. Turk. J. Zool. 35, 271, 2011. 
15. LEE S.V., CUNDY A.B. Heavy metal contamination and mixing processes in sediments from the Humber Estuary, Eastern England. Estuar. Coast. Shelf Sci. 53, 619, 2001.

16. FU F. WANG Q. Removal of heavy metal ions from wastewaters: A review. J. Environ. Manage. 92, 407, 2011.

17. PRICA M., DALMACIJA B., RONCEVIC S., KRCMAR D., BECELIC M. A comparison of sediment quality results with acid volatile sulfide (AVS) and simultaneously extracted metals (SEM) ratio in Vojvodina (Serbia) sediments. Sci. Total Environ. 389, 235, 2008.

18. YANG Y., CHEN F., ZHANG L., LIU J., WU S., KANG M. Comprehensive assessment of heavy metal contamination in sediment of the Pearl River Estuary and adjacent shelf. Mar. Pollut. Bull. 64, 1947, 2012.

19. FATOKI O.S., MATHABATHA S. An assessment of heavy metal pollution in the East London and Port Elizabeth harbours. Water SA. 27, 233, 2001.

20. IP C.C.M., XI X.D., ZHANG G., WAI O.W.H., LI Y.S. Trace metal distribution in sediments of the Pearl River Estuary and the surrounding coastal area, South China. Environ. Pollut. 147, 311, 2007.

21. YU R., YUAN X., ZHAO Y., HU G., TU X. Heavy metal pollution in intertidal sediments from Quanzhou Bay, China. J. Environ. Sci. 20, 664, 2008.

22. HOSONO T., SU C., DELINOM R., UMEZAWA Y., TOYOTA T., KANEKO S., TANIGUCHI M. Decline in heavy metal contamination in marine sediments in Jakarta Bay, Indonesia due to increasing environmental regulations. Estuar. Coast. Shelf Sci. 92, 297, 2011.

23. PAN J., PAN J.F., WANG M. Trace elements distribution and ecological risk assessment of seawater and sediments from Dingzi Bay, Shandong Peninsula, North China. Mar. Pollut. Bull. 89, 427, 2014.

24. ASHRAF W., SEDDIGI Z., ABULKIBASH A., KHALID M. Levels of selected metals in canned fish consumed in Kingdom of Saudi Arabia. Environ. Monit. Assess. 117, 271, 2006.

25. ULUOZLU O.D., TUZEN M., MENDIL D., SOYLAK M. Trace metal content in nine species of fish from the Black and Aegean Seas, Turkey. Food Chem. 104, 835, 2007.

26. TUZEN M. Toxic and essential trace elemental contents in fish species from the Black Sea, Turkey. Food Chem. Toxicol. 47, 1785, 2009.

27. GAO X.L., ZHOU F.X., CHEN C.T.A. Pollution status of the Bohai Sea, China: An overview of the environmental quality assessment related trace metals. Environ. Int. 62, 12, 2014.

28. KARAGEORGIS A.P., KABERI H., PRICE N.B., MUIR G.K.P., PATES J.M., LYKOUSIS V. Chemical composition of short sediment cores from Thermaikos Gulf (Eastern Mediterranean): Sediment accumulation rates, trawling and winnowing effect. Cont. Shelf Res. 25, 2456, 2005.

29. ROMANO E., BERGAMIN L., AUSILI A., PIERFRANCESCHI G., MAGGI C., SESTA G., GABELLINI M. The impact of the Bagnoli industrial site (Naples, Italy) on sea-bottom environment. Chemical and textural features of sediments and the related response of benthic foraminifera. Mar. Pollut. Bull. 59, 245, 2009.

30. GALANOPOULOU S., VGENOPOULOS A., CONISPOLIATIS N. Anthropogenic heavy metal pollution in the surficial sediments of the Keratsini Harbor, Saronikos Gulf, Greece. Water Air Soil Poll. 202, 121, 2009.

31. ALVAREZ-IGLESIAS P., RUBIO B. Redox status and heavy metal risk in intertidal sediments in N.W. Spain as inferred from the degrees of pyritization of iron and trace elements. Mar. Pollut. Bull. 58, 542, 2009.
32. DGPA. Annuaires des statistiques des produits de la pêche. Ministère de l'Agriculture, Tunisie, 2004.

33. BEN REBAH F., ABDELMOULEH A., KAMMOUN W., YEZZA A. SEASONAL VARIATION OF LIPID CONTENT AND FATTY ACID COMPOSITION OF Sardinella aurita from the Tunisian coast. J. Mar. Biol. Assoc. U.K. 90, $569,2010$.

34. DRIRA Z., HAMZA A., BEL HASSEN M., AYADI H., BOUAIIN A., ALEYA L. Dynamics of dinoflagellates and environmental factors during the summer in the Gulf of Gabes (Tunisia, Eastern Mediterranean Sea). Sci. Mar. 72, 59, 2008.

35. DRIRA Z., BEL HASSEN M., HAMZA A., REBAI A., BOUAIN A., AYADI H., ALEYA L. Spatial and temporal variations of microphytoplankton composition related to hydrographic conditions in the Gulf of Gabes. Mar. Biol. Assoc. U.K. 89, 1559, 2009.

36. DRIRA Z., BEL HASSEN M., AYADI H., HAMZA A., ZARRAD R., BOUAÏN A., ALEYA L. Copepod community structure related to environmental factors from a summer cruise in the Gulf of Gabes (Tunisia, eastern Mediterranean Sea). Mar. Biol. Assoc. U.K. 90, 145, 2010a.

37. DRIRA Z., HAMZA A., BEL HASSEN M., AYADI H., BOUAÏN A., ALEYA L. Coupling of phytoplankton community structure to nutrients, ciliates and copepods in the Gulf of Gabes (south Ionian Sea, Tunisia). Mar. Biol. Assoc. U.K. 90, 1203, 2010b.

38. DRIRA Z., BEL HASSEN M., AYADI H., ALEYA L. What factors drive copepod community dynamics in the Gulf of Gabes, Eastern Mediterranean Sea? Environ. Sci. Pollut. Res. 21, 2918, 2014.

39. BEN BRAHIM M., HAMZA A., HANNACHI I., REBAI A., JARBOUI O., BOUAIN A., ALEYA L. Variability in the structure of epiphytic assemblages of Posidonia oceanica in relation to human interferences in the Gulf of Gabes, Tunisia. Mar. Environ. Res. 70, 411, 2010.

40. DRIRA Z., KMIHA-MEGDICHE S., SAHNOUN H., HAMMAMI A., ALLOUCHE N., TEDETTI M., AYADI $\mathrm{H}$. Assessment of anthropogenic inputs in the surface waters of the southern coastal area of Sfax during Spring (Tunisia, Southern Mediterranean Sea). Mar. Pollut. Bull. 104, 355, 2016.

41. TAYIBI H., CHOURA M., LÓPEZ F.A., ALGUACIL F.J., LÓPEZ-DELGADO A. Environmental impact and management of phosphogypsum. J. Environ. Manage. 90, 2377, 2009.

42. CALLAERT B., VAN DEN BOGAERT J., PIETERS A., PYNAERT K., TISON P., LEVRAU K. Taparura Project: Sustainable coastal development, including the decontamination and rehabilitation of the coastal area of the city of Sfax, Tunisia. Coastal and Maritime Mediterranean Conference 175, 2009.

43. ZAGHDEN H., KALLEL M., LOUATI A., ELLEUCH B., OUDOT J., SALIOT A. Hydrocarbons in Surface Sediments from the Sfax coastal zone, (Tunisia) Mediterranean Sea. Mar. Pollut. Bull. 50, 287, 2005.

44. ZAGHDEN H., KALLEL M., ELLEUCH B., OUDOT J., SALIOT A., SAYADI S. Evaluation of hydrocarbon pollution in marine sediments of Sfax coastal areas from the Gabes Gulf of Tunisia, Mediterranean Sea. Environ. Earth Sci. 72, 1073, 2014.

45. SERBAJI M.M., AZRI C., MEDHIOUB K. Anthropogenic contributions to heavy metal distributions in the surface and sub-surface sediments of the northern coast of Sfax, Tunisia. Int. J. Environ. Res. 6, 613, 2012.

46. MEZGHANI-CHAARI S., HAMZA A., HAMZA-CHAFFAI A. Mercury contamination in human hair and some 
marine species from Sfax coasts of Tunisia: levels and risk assessment. Environ. Monit. Assess. 180, 477, 2011.

47. HAMZA-CHAFFAI A., PELLERIN J., AMIARD J.C. Health assessment of a marine bivalve Ruditapes decussatus from the Gulf of Gabes (Tunisia). Environ. Int. 28, 609, 2003.

48. SMAOUI-DAMAK W., REBAI T., BERTHET B., HAMZA-CHAFFAI A. Does cadmium pollution affect reproduction in the clam Ruditapes decussates? A 1-year case study. Comp. Physiol. Biochem. Part C 143, 252, 2006.

49. TAMASI G., CINI R. Heavy metals in drinking waters from Mount Amiata. Possible risks from arsenic for public health in the province of Siena. Sci. Tot. Environ. 327, 41, 2004.

50. USEPA. National recommended water quality criteria-Correction: EPA 822/Z-99-001, 1999.

51. SPANOS C. Analysis of Trace Elements in Seawater Using the Thermo Scientific iCAP 7000 Series ICP-OES Duo Applications Chemist, Thermo Fisher Scientific. Cambridge, UK, Application Note 43185, 2014.

52. CAERIO S., COSTA M.H., RAMOS T.B., FERNANDES F., SILVEIRA N., COIMBRAA., MEDERIOS G., PAINHO M. Assessing heavy metal contamination in sado Estuary sediment: an index analysis approach. Ecol. Indic. 5, 155, 2005.

53. GHANNEM N., AZRI C., SERBAJI M.M., YAICH C. Spatial Distribution of Heavy Metals in the Coastal Zone of "Sfax-Kerkennah" Plateau, Tunisia. Environ. Prog. Sustain. Energy. 30, 221, 2011.

54. IRNAWATI R., SUSANTO A., MUSTAHAL, SYABANA M.A. Heavy metals concentration in water and sediment at Panjang Island, Serang Regency, Banten Province, Indonesia. Adv. Environ. Advances in Environmental Sciences - International Journal of the Bioflux Society 6, 256, 2014.

55. BEN SALEM Z., AYADI H. Assessment of heavy metal contamination levels and toxicity in sediments and fishes from the Mediterranean Sea (southern coast of Sfax, Tunisia). Environ. Sci. Pollut. Res. 23, 13954, 2016a.

56. BEN SALEM Z., AYADI H. Heavy metal accumulation in Diplodus annularis, Liza aurata, and Solea vulgaris relevant to their concentration in water and sediment from the southwestern Mediterranean (coast of Sfax). Environ. Sci. Pollut. Res. 23, 13895, 2016b.

57. ABDALLAH M.A.M. Trace Metal Behavior in Mediterranean-Climate Coastal Bay: El-mex Bay, Egypt and its Coastal Environment. Global J. Environ. Res. 2, 23, 2008.

58. MENSI G.S., MOUKHA S., CREPPY E.E., MAAROUFI K. Metals Accumulation in Marine Bivalves and Seawater from the Lagoon of Boughrara in Tunisia (North Africa). Int. J. Environ. Res. 2, 279, 2008

59. NASRI I., HAMMOUDA A., HAMZA F., ZRIG A., SELMI S. Heavy metal accumulation in lizards living near a phosphate treatment plant: possible transfer of contaminants from aquatic to terrestrial food webs. Environ. Sci. Pollut. Res. 67, 1, 2015.

60. BEJAOUI B., RAÏS S., KOUTITONSKY V. Modélisation de la dispersion du phosphogypse dans le Golfe de Gabès. Bull. Inst. Nat. Scien. Tech. Mer Salammbô. 31, 103, 2004.

61. AYADI N., ALOULOU F., BOUZID J. Assessment of contaminated sediment by phosphate fertilizer industrial waste using pollution indices and statistical techniques in the Gulf of Gabes (Tunisia). Arab. J. Geosci. 8, 1755, 2015.

62. ILLOU S. Impact des rejets telluriques d'origines domestiques et industrielles sur l'environnement côtier : cas de littoral de la ville de Sfax. Thèse de doctorat, Université de Tunis (in French), 1999

63. LAHBIB Y., MLEIKI A., TRIGUI-EL MENIF N. Bioaccumulation of trace metals in Hexaplex trunculus: spatial and temporal trends from 2004 to 2011 along the Tunisian coast. Environ. Sci. Pollut. Res. 23, 16259, 2016.

64. DARMOUL B. Pollution dans le Golfe de Gabès (Tunisie): Bilan des six années de surveillance (1976-1981). Bull. Ins. Nat. Sci. Tech. Mer Salammbô 15, 61, 1988.

65. DARMOUL B., VITIELLO P. Recherches expérimentales sur la toxicité aiguë des rejets de phosphogypse sur quelques organismes benthiques marins. Bull. Inst. Nat. Scient. Tech. Oceanogr Pêche Salammbô 7, 63, 1980.

66. KHARROUBI A., GARGOURI D., BAATI H., AZRI C. Assessment of sediment quality in the Mediterranean SeaBoughrara lagoon exchange areas (southeastern Tunisia): GIS approach-based chemometric methods. Environ. Monit. Assess. 184, 4001, 2012.

67. EL ZRELLI R., COURJAULT-RADÉ P., RABAOUI L., CASTET S., MICHEL S., BEJAOUI N. Heavy metal contamination and ecological risk assessment in the surface sediments of the coastal area surrounding the industrial complex of Gabes city, Gulf of Gabes, SE Tunisia. Mar. Pollut. Bull. 101, 922, 2015.

68. RABAOUI L., EL ZRELLI R., BEN MANSOUR M., BALTI R., MANSOUR L., TLIG-ZOUARI S., GUERFEL $\mathrm{M}$. On the relationship between the diversity and structure of benthic macroinvertebrate communities and sediment enrichment with heavy-metals in Gabes Gulf, Tunisia. Mar. Biol. Assoc. U.K. 95, 233, 2015.

69. ROUIS M.G., BEN SALAH A., BALLIVY G. Phosphogypsum management in Tunisia: environmental problem and required solutions. Proc Third Int Symp Phosphogypsum, Orlando FL 1:87-105, FIPR Pub. №1-060-083, 1990.

70. PERGENT G., KEMPF M. L'environnement marin côtier en Tunisie. Rapport de synthèse, Etude documentaire, Annexes. Rapport IFREMER DEL Brest 92.06., 1993

71. ABDELRAHIM A.A., ELHADI M.E., MOHAMED A.A. Determination of Heavy Metals in Four Common Fish, Water and Sediment Collected from Red Sea at Jeddah Isalmic Port Coast. J. Appl. Environ. Biol. Sci. 1, 453, 2011.

72. BAZZI A.O. Heavy metals in seawater, sediments and marine organisms in the Gulf of Chabahar, Oman Sea. J. Oceanogr. Mar. Sci. 5, 20, 2014.

73. ELKADY A.A., SWEET S.T., WADE T.L., KLEIN A.G. Distribution and assessment of heavy metals in the aquaticenvironment of Lake Manzala, Egypt. Ecol. Indic. 58, 445, 2015.

74. JAMES W.M. Inorganic contaminations of surface water: Research and monitoring properties. Springer-Veralag, New York, 1991.

75. EL BOURAIE M.M., EL BARBARY A.A., YEHIA M.M., MOTAWEA E.A. Heavy metal concentrations in surface river water and bed sediments at Nile Delta in Egypt. Suo. 61, 1, 2010

76. ZHANG L., SHI Z., JIANG Z., ZHANG J., WANG F., HUANG X. Distribution and bioaccumulation of heavy metals in marine organisms in east and west Guangdong coastal regions, South China. Mar. Pollut. Bull. 101, 930, 2015.

77. ZAIRI M., ROUIS M.J. Impacts environnementaux du stockage du phosphogypse à Sfax (Tunisie). Bulletin des Laboratoires des Ponts et Chaussées, 1999.

78. ATSDR. Agency for Toxic Substances and Disease Registry Toxicological Profile for Zinc. August 2005, 2005.

79. 79. EIP Associates. Zinc Source Identification. Prepared for Palo Alto Regional Water Quality Control Plant, 1999.

80. KOZLOVA T., WOOD C.M., MC GEER J. C. The effect of water chemistry on the acute toxicity of nickel to the cladoceran Daphnia pulex and the development of a biotic ligand model. Aquat. Toxicol. 91, 221, 2009. 
81. CEMPEL M., NIKEL G. Nickel: A review of its sources and environmental toxicology. Pol. J. Environ. Stud. 15, 375, 2006.

82. HARTE J., HOLDREN C., SCHNEIDER R., SFDRLEY C. Toxic A to Z: A Guide to Everyday Pollution Hazards. University of California Press, Berkeley, 1991.

83. AYED N., FAURE E., QUIGNARD J.P., TRABELSI M. Determination of $\mathrm{P}, \mathrm{Ca}, \mathrm{Zn}, \mathrm{Cd}$ and $\mathrm{Pb}$ Concentrations in Muscle, Gills, Liver, Gonads and Skeletons of Two Natural Populations of Atherina Lagunae in North Tunis Lake, Tunisia. J. Water Resource Prot 3, 421, 2011.

84. NUSSEY G., VAN VUREN J.H., DU PREEZ H.H. Bio- accumulation of Chromium, Manganese, Nickel and Lead in the Tissues of the Moggel, Labeo Umbratus (Cyprini- dae), from Witbank Dam, Mpumalanga. Water SA, 26, 2000.

85. GRANÉLI E., MOREIRA M.O. Effects of river water of different origin on the growth of marine dinoflagellates and diatoms in laboratory culture. J. Exp. Mar. Biol. Ecol. 136, 153, 1990.

86. TAM N.F.Y., WONG Y.S. Spatial variation of heavy metals in surface sediments of Hong Kong mangrove swamps. Environ. Pollut. 110, 195, 2000.

87. HARUNA A., UZAIRU A., HARRISON G.F.S. Chemical Fractionation of Trace Metals in Sewage Water-Irrigated Soils. Int. J. Environ. Res. 5, 733, 2011.
88. SHARIATI F., SARI E.A., MORADI A.M., POURKAZEMI M. Metal bioaccumulation in Persian sturgeon after sublethal exposure. Int. J. Mar. Sci. Eng. 2, 81, 2012.

89. GHADERI A.A., ABDULI M.A., KARBASSI A.R., NASRABADI T., KHAJEH M. Evaluating the Effects of Fertilizers on Bioavailable Metallic Pollution of soils, Case study of Sistan farms, Iran. Iran Int. J. Environ. Res. 6, 565, 2012.

90. WANG S.L., XU X.R., SUN Y.X., LIU J.L., LI H.B. Heavy metal pollution in coastal areas of South China: A review. Mar. Pollut. Bull. 76, 7, 2013.

91. ALOULOU F., ELLEUCH B., KALLEL M. Benthic foraminiferal assemblages as pollution proxies in the northern coast of Gabes Gulf, Tunisia. Environ. Monit. Assess. 184, 777, 2012.

92. BARHOUMI S., MESSAOUDI I., DELI T ., SAÏD K., KERKENI A. Cadmium bioaccumulation in three benthic fish species, Salaria basilisca, Zosterisessor ophiocephalus and Solea vulgaris collected from the Gulf of Gabes in Tunisia. J. Environ. Sci. 21, 980, 2009.

93. BOUGUERRA M.L. Chemical analysis: pollution and pesticide residue in North Africa. Trac-Trends Anal Chem. 3, 91, 1994.

94. KANNA N., TOYOTA T., NISHIOKA J. Iron and macronutrient concentrations in sea ice and their impact on the nutritional status of surface waters in the southern Okhotsk Sea. Prog. Oceanogr. 126, 44, 2014. 
